\title{
LAW ENFORCEMENT EFFECTS ON SOCIAL DISCIPLINE AND COMMUNITY SOCIAL INTEGRATION IN GARUT DISTRICT
}

\author{
By \\ Uus Sunandar ${ }^{1}$, Abdal $^{2}$ \\ 1,2Ministry of Law and Human Rights \& State Islamic University SGD Bandung \\ Email: ${ }^{1}$ u.sunandar_kumham@yahoo.com, ${ }^{2}$ abdal@ uinsgd.ac.id
}

\begin{tabular}{l}
\hline \hline Article Info \\
\hline Article History: \\
Received:16-10-21 \\
Revised : $16-11-21$ \\
Accepted: $24-11-2021$ \\
\\
\hline Keywords: \\
law enforcement, social \\
discipline and social integration
\end{tabular}

Corresponding Author:

Uus Sunandar, Abdal,

Ministry of Law and Human Rights \& State Islamic University SGD Bandung,

Indonesia.

Email: u.sunandar_kumham@yahoo.com, abdal@uinsgd.ac.id

\begin{abstract}
This research background was the less optimum of law enforcement that has caused the social discipline and social integration weakness in Garut regency. Based on it, core problem of this reseacrh was identifying as: "has the law enforcement affected the social discipline and social integration in Garut regency?". On this research has used descriptive analysis method, and the population has taken is 7 person attorney in Garut regency, 11 person judge of Garut regency, 10 person police functionary administrative unit for regency, and 396 person of village representative institution chairman (BPD) as Garut Community representatives.In the interest of research, has taken 108 persons respondents. Path Analysis has used as data analyze technique to answer the hypothesis. From the examination show that law enforcement and social discipline had been effecting simutaneously to the social integration, for $62.90363 \%$ and the rest of $37.09637 \%$ effected by others variable. From partial examination has known that law enforcement and social discipline effecting for real to the social integration. Law enforcement has positive effect to the social integration and it can be identified through path other variable effect value is $39.59919 \%$. In other hand, partial effect of social discipline has shown the real effect to social integration, with path of others variable is $74.62376 \%$. Based on the result, concluded that law enforcement has significantly effected to social discipline and social integration in Garut regency. So, recommended to pay the special attention to the aspect without ignoring others aspect with might effect social discipline and social integration.
\end{abstract}

This is an open access article under the CC BY-SA license.

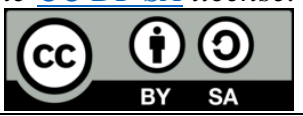

\section{INTRODUCTION}

Indonesia is currently entering an era of transition, both in the fields of politics, law, economy, and socioculture, which is followed by the occurrence of shocking symptoms in these five fields, which in turn creates unique and serious problems that are not easy to solve. Handled quickly, both by the government and by law enforcement officials.

The objective conditions in the five fields mentioned above, which are currently developing in this reform era, are nothing but a broad and deep and even distribution of causes and effects from the less or less democratic practices of the state administration during the New Order government. Honestly, it must be admitted that everything is the result of political behavior, from some of them who currently speak and act pro-reform.

The economic, socio-cultural and political fields may be affected by the transition period, but the legal field, both in the sense of the law that is currently in force (iusconstitutum) and the law that will apply or is being drafted (iusconstituendum) must continue to be carried out, even a legal comparison is needed. (Iuscimparandum) with other countries that have a system of constitutional development similar to Indonesia should be used as a reference in the formation of national law. 
The process of law enforcement and the process of forming national laws (law making process) are interrelated with each other because a good, correct, and responsible law enforcement process can be influenced by a process of law formation that is aspirational, proactive and credible at its time. The process of forming aspirational, proactive and credible laws can only take place properly if it is implemented by fulfilling 3 (three) main corridors, namely, the academic corridor (the preparation of academic texts), the administrative corridor (horizontal coordination between relevant departments) and the socio-political corridor (discussion by government together with the DPR), so that in the process of law formation it is necessary to include and consider the obstacles in law enforcement.

In the process of law formation, public participation also needs to be increased as an important part of the effort to spread the law evenly (law illumination process). The factors that hinder the effectiveness of law enforcement do not only lie in the mental attitude of law enforcement officials (judges, prosecutors, police and legal advisors) but also lies in the factor of legal socialization which is often ignored.

The existence of public demands to obtain justice and the implementation of all applicable laws and regulations is the obligation and responsibility of the government and law enforcers to pay attention to it. It is not possible to change all mental attitudes from negative to positive, from not being aware of the law to being aware of the law, all of which require a process. But what is important is that efforts to fertilize, foster and develop legal awareness must continue in a planned and sustainable manner accompanied by examples from various parties who feel they understand and understand the law.

The problem that often arises in the community related to the demands of law enforcement is the problem of social injustice, which in the context of Indonesia during the New Order era was caused by the failure of the development paradigm that was based on economic growth alone.

Law enforcement has a very important role, in order to create conducive social conditions for society and avoid anarchy. Correct and fair law enforcement will play a role in the creation of a disciplined and integrated social life of the community, as well as being able to suppress law violations in people's lives.

The phenomenon of law enforcement in relation to the creation of a disciplined and integrated social life of society in Garut district which is an integral part of the Indonesian nation and is the object of location in the interests of this thesis research, according to the author's observations so far, can be stated as follows:

1) Law enforcement in Garut Regency is still weak, so that law violations often occur by the community, such as in the form of vigilantism, as well as acts that are not required by law such as committing criminal acts (murder, theft, rape and others), juvenile delinquency, inter-period commotion that will disturb the order and peace of the environment.

2) The socialization of legal awareness to the public is not carried out optimally by law enforcement officers. In fact, socialization that is directed and fostered will be able to create legal awareness in the community which in turn can lift society towards a better direction, free from feelings of anxiety that are haunted by feelings of fear.

3) The implementation of socialization of legal awareness that is less than optimal has implications for the conditions of social life of people who are less disciplined. People are less aware of the importance of law enforcement, so that the conditions of social life of the community have not been well integrated, which is marked by cooperation in the community that has not been established harmoniously.

\section{Theoretical Foundation}

\section{Law Enforcement}

UUD 1945 emphasized that Indonesia is a state based on law, not a state based on mere power. The law that becomes the sign of controlling power can be realized in many forms, such as laws, government regulations, or presidential decrees and has become a general principle in the legal system adopted in Indonesia, and is the main instrument in controlling the life of the nation and state.

The reality often shows otherwise or contradicts these general principles, which is caused by many factors, including the lack of understanding of state administrators about the national legal system that has been institutionalized to date. In addition to these factors, the lack of public understanding of the law and the applicable legal system (legal awareness) is often a trigger factor for state administration without law (legal chaos) or legal crises that end in people's distrust of the law (Manan, 1996: 51).

The public's distrust of the law is getting deeper, this is due to the enforcement that has stagnated or even seems stagnant, especially in criminal cases (criminals), both since the investigation, detention, prosecution and court examination. Diseases of corruption, collusion and nepotism within the scope of law enforcement tasks that have developed so far are actually a malignant cancer that can undermine the resilience of the nation and state at any time. 
This situation is due to the fact that the formation of laws and regulations has not guaranteed the implementation of effective law enforcement.

The formation of laws and regulations that have not guaranteed the implementation of law enforcement according to Atmasasmita (2001: 11) is caused by:

1) The substance of the legislation is incomplete and there are still loopholes, thus providing opportunities for abuse of authority by law enforcement officials.

2) The substance of laws and regulations overlaps with each other, giving rise to different interpretations between law enforcement officials and providing opportunities to sterilize laws and regulations in cases that are full of conflicts of interest.

3) There is a substance in the legislation that still places the interests of the government too high above the interests of the wider community.

4) There is still no clear distinction between executive, judicial and legislative functions.

5) The awareness and responsibility of the nation and state in producing laws and regulations and enforcing the law is still weak. These weaknesses appear as a link in the chain of weaknesses in the fields of social, cultural and political development that have been implemented so far.

Muladi (Manan, 1996: 40) suggests that in the process of law formation, public participation needs to be increased as an important part of efforts to enforce the law fairly. Law enforcement in the transitional era should not recede, because the transition period is not an excuse not to enforce it properly, correctly and responsibly. The process of law enforcement and the process of law formation are interrelated with each other, because a good, correct and responsible law enforcement process can be influenced by the aspirational, proactive and credible law formation process at its time.

In law enforcement practice inequalities often occur, according to Busroh and Busro (1994: 81) that the inequality can actually be returned to the problem of the gap between the law making process, the law illumination process and the law enforcement process.

The problems of law enforcement that often arise are very likely caused by the three processes mentioned above which have undergone a process of disequilibrium that is not systematically monitored, even not controlled properly and responsibly. The looting, destruction, arson and rape that occurred in the transitional era, which has occurred at this time, are the result of a "trial and error" process that commonly occurs in the transitional era in the political, economic, social and cultural fields. Violence, both individually and collectively or by elite groups, requires firm, consistent, and continuous legal control.

According to Manan (1996: 15) these legal constraints can be answered by the following three policies:

1. The policy is preventive in nature (preventive policy).

2. Repressive policies.

3. Rehabilitative policy.

Law enforcement practices, which are often controversial in legal life in Indonesia, cannot be separated from the law enforcement management system. This approach to the law enforcement management system seems to have received less attention, because at the time of its preparation, great attention was focused on how to place the positions of the Police, Judges, Prosecutors, Correctional Institutions and Legal Advisors on the one hand and the positions of suspects or defendants in criminal justice on the other. To lay the foundations of a good and directed management system, it is necessary to implement the Criminal Procedure Code which is measured by juridical legitimacy for the duties and authorities of the judiciary (Atmasasmita, 2001: 32).

Furthermore, Atmasasmita (2001: 33) suggests that the strategic steps taken by the government in its implementation include: Studying the basic law and legislation, the formation of laws and regulations, legal counseling and the ideals of one roof law enforcement education.

2. Social Discipline

Community life as a social unit, both household units, groups and other institutions is a system. So every society is a kind of organization of various individual interests, rules, and their attitudes towards each other, where this relationship produces a system or order known as a social structure.

Social structure cannot be separated from social interaction, which is a process in which humans influence each other by formulating their thoughts, feelings, hopes and anxieties. Thus, the social structure includes all dimensions of relationships between individuals in society (Iskandar, 2001: 189).

One of the dimensions of social structure is social discipline which is also referred to in the terminology of social order. Social discipline which is the term in this discussion is part of a social process which is a means to achieve all activities in society through efforts to disseminate value systems by individuals or groups (Campbell, 
1994: 7). In the literature of the social sciences, one of the efforts to foster social discipline can be done by means of social control.

Social control according to Iskandar (2001: 200) is the way and process taken by a group of people or society to be able to act in accordance with the expectations of the group or society. Social discipline is created when people's activities are fun and predictable. No society, even the simplest society, can work well if the behavior of most members of that society is not always predictable.

Iskandar (2001: 201) suggests that in a simple society, socialization creates social order - in the sense of a disciplined social community - by preparing people to be willing to behave as expected, and social pressure rewards in the form of acceptance and recognition whenever people behave as expected. In a more complex society, more power is needed to ensure the continuity of social discipline.

Soekanto (1994: 93) suggests that the process of building social discipline can be carried out by groups in society through social control. Because the group has a strong influence in shaping the behavior of its members.

Iskandar (2001: 201-203) suggests that groups in society can be divided into two types, namely primary groups and secondary groups. Primary groups are small, intimate, and informal groups, such as families and play groups. While secondary groups are groups that are impersonal, formal and based on interests, such as trade union organizations, trade business associations, or student organizations.

Control in the primary group occurs informally, spontaneously, and unplanned. Group members react to each other's behavior. When a member hurts or offends other members, they may show their displeasure by mocking, laughing, criticizing or even removing the member from the association. When a member's behavior is pleasant, the reward that is usually received is the feeling of being received pleasantly.

Secondary group control is more formal. These groups are not used to fulfill our need for intimate and human relationships, but to assist in getting some work done. When the secondary group is unable to meet our needs, we can generally withdraw without feeling deeply saddened, because the emotional involvement with it is not deep. Usually the secondary group is a weaker controlling institution than the primary group. Despite this fact, secondary groups are still an effective control tool. More formal control is a characteristic possessed by the secondary group. All of these formal control methods will be very effective if they are supported by the primary group. The main part of social control is in the form of efforts to control situational behavior, because most people will react according to situational stimuli that arise.

3. Community Social Integration

An important figure in the theory of social integration is Emile Durkheim, a major classical figure in sociology whose theoretical approach emphasizes the level of analysis of social structures and pays attention to social processes that increase integration and solidarity in society. In his view, he argues that social phenomena are objects (The Rules of Sociological Method). This means that social phenomena are objectively real, with an existence independent of individual biological or psychological symptoms (Iskandar, 2001: 380).

The basic methodological principle in the analysis of society which is emphasized by Durkheim (Iskandar 2001: 382) is that social facts must be explained in relation to other social facts, and the origin of a social phenomenon and its functions are two separate problems.

Durkheim (Campbell, 1994: 164) suggests three characteristics that distinguish social phenomena from truly individual symptoms, namely:

1. Social phenomena are external to the individual.

2. Facts compel individuals,

3. Facts are general or spread widely in one society.

These three characteristics (externality, coercion and generality) describe the type of phenomenon he sees as the main problem in sociology. Social solidarity and social integration may be seen as examples of a social fact that is external to the individual and cannot be explained according to individual characteristics.

Iskandar (2001: 382-383) suggests that to understand the social integration that exists in society, it is necessary to analyze its social structure. The two types of social structure in Durkheim's theory reflect differences in the extent of the division of labor and in the main forms of social solidarity. The two types of solidarity are mechanical solidarity and organic solidarity.

A society based on mechanical solidarity has a very high degree of division. The high level of interdependence is a strong result as a source of solidarity. Furthermore, society develops from mechanical solidarity to organic solidarity, but collective consciousness does not disappear entirely in organic society. For more details, the difference between mechanical solidarity and organic solidarity can be seen in the following table: 
International Journal of Social Science (IJSS)

Vol.1 Issue.4 December 2021, pp: 423-430

ISSN: 2798-3463 (Printed) | 2798-4079 (Online)

DOI: https://doi.org/10.53625/ijss.v1i4.720

Table 1

The Difference Between Mechanical Solidarity and Organic Solidarity

\begin{tabular}{|c|c|}
\hline MECHANICAL SOLIDARITY & ORGANIC SOLIDARITY \\
\hline $\begin{array}{l}\text { - } \text { Low division of labor } \\
\text { - Strong collective consciousness } \\
\text { - } \text { Dominant repressive law } \\
\text { - } \text { Low individuality } \\
\text { imponsuntant on normative patterns is } \\
\text { - Community involvement in punishing } \\
\text { deviants } \\
\text { - Relatively low interdependence } \\
\text { Primitive-rural nature }\end{array}$ & $\begin{array}{ll}\text { - } & \text { High division of labor } \\
\text { - } & \text { Weak collective consciousness } \\
\text { - } & \text { High individuality } \\
\text { - } & \text { Consensus on abstract and general values } \\
& \text { is important } \\
\text { - } & \text { Social control bodies that punish deviants } \\
- & \text { High interdependence } \\
\text { - } & \text { Industrial-urban nature }\end{array}$ \\
\hline
\end{tabular}

Source: Iskandar (2001: 383)

As understood from various sources, that which threatens social integrity are conflicts between groups, deviations, excessive individualism and anomie are pointed out as potential threats, especially during the transition period to a new type of structure. Social integrity refers to a state of relationships between individuals or groups based on shared moral feelings and beliefs that are strengthened by shared emotional experiences.

\section{RESEARCH METHOD}

The research design used in this research is descriptive analysis. To collect data, data collection techniques were used: Observation, Questionnaire, Interview and Documentation Study. The data analysis technique used is Statistical Analysis with Path Analysis model. Al-Rasyid (1995: 122) suggests that path analysis is a method to determine causal relationships with the aim of separating the direct and indirect effects of independent and dependent variables.

\section{RESULTS AND DISCUSSION}

That the average respondent's answer to the law enforcement variable is good, which is $77.08 \%$ of all questions on that variable. This situation illustrates the positive understanding and perception of respondents on law enforcement issues. The indicator with the highest percentage value on this law enforcement variable is: Every citizen who violates the applicable legal provisions must be subject to legal sanctions commensurate with his actions, with a percentage of $83.15 \%$. This result is theoretically in accordance with the principle of law enforcement, namely anyone who violates the law must be subject to legal sanctions in accordance with applicable legal provisions indiscriminately.

The indicators with the lowest percentage on this law enforcement variable are: Legal reform must be carried out simultaneously, with a percentage value of $61.85 \%$. This condition is more due to the absence of clear, firm and comprehensive regulations regarding the operationalization of legal reform policies.

Furthermore, the average respondent's answer to the Social Discipline variable is good, namely $73.35 \%$ of all questions on that variable. These results indicate that respondents have a positive understanding and perception of social discipline problems.

The indicators with the highest percentage value on this social discipline variable are: Social norms can influence the disciplinary behavior of citizens, with a percentage value of $85.93 \%$. This situation is theoretically in accordance with the opinion which states that one of the efforts to build social discipline is to exercise social control through social norms.

The indicators with the lowest percentage value on this social discipline variable are: The government (law enforcement apparatus) has an obligation to provide legal counseling to the public, with a percentage value of $56.30 \%$. These results illustrate that the government, especially law enforcement officers, is less intensive in conducting legal counseling to the public. This theoretically will greatly affect the slow pace of efforts to build social discipline in society. 
Then the average respondent's answer to the Social Integration variable is good, which is $74.86 \%$ of all questions on that variable. This situation shows that respondents have a positive understanding and perception about the condition of social integration in the Garut district.

The indicators with the highest percentage values for this variable are: The level of individuality in the community in your environment is very high, with a percentage of $82.96 \%$, while the indicators with the lowest percentages are: Community participation has an important role in efforts to build a conducive social environment, with a percentage value of by $67.78 \%$. These results illustrate that the main problem that must be immediately anticipated in order to build community social integration is to reconstruct the social solidarity of the community which has begun to fade by the climate of individuality, so that in turn it will be able to grow a high level of community participation in an effort to build their social environment in a conducive manner.

To determine the significance of the effect of the law enforcement variable (X) on Social Discipline (Y) carried out through statistical testing using the t-student statistical approach with the test criteria being at the significance level if the tvalue is greater than t-table.

From the test results, it turns out that law enforcement (X) has a significant effect on Social Discipline (Y). This is obtained from the results of the tcount of 6.411257 and the ttable obtained from the student distribution table with degrees of freedom $(\mathrm{dk}=106)$ of 2 , so based on the test criteria, the conclusion is that it is at the significance level.

The significance of the effect of the law enforcement variable $(\mathrm{X})$ on social discipline $(\mathrm{Y})$ is also shown through the value of the coefficient of influence on testing this hypothesis of $37.332 \%$, and the external influence on this variable is $62.668 \%$.

To determine the significance of the effect of the law enforcement variable $(X)$ on the social integration of the community $(\mathrm{Z})$ it is carried out through statistical testing using the $\mathrm{t}$-student statistical approach with the test criteria being at the significance level if the $t$-count value is greater than the t-table.

From the results of the tests carried out, it turns out that law enforcement $(\mathrm{X})$ has a significant effect on the social integration of the community $(\mathrm{Z})$. This is obtained from the results of the calculated t value of 6.842064 and the $t$ table obtained from the student distribution table with degrees of freedom $(\mathrm{dk}=106)$ of 2 , so based on the test criteria, the conclusion is that it is at the significance level.

The significance of the effect of the law enforcement variable $(X)$ on the social integration of the community ( $\mathrm{Z}$ ) is also shown through the value of the coefficient of influence on testing this hypothesis of $60.40081 \%$, and the external influence on this variable is $39.5992 \%$. This is obtained from the direct effect (variable $\mathrm{X}$ to variable $\mathrm{Z}$ ) of $40.75225 \%$ and indirect effect (variable $\mathrm{X}$ to variable $\mathrm{Z}$ through variable $\mathrm{Y}$ ) of $19.64856 \%$.

Based on the test results above, law enforcement has a real influence on Community Social Integration. This can be seen from the path coefficient value of 0.638375 , and the value of the coefficient of influence on testing this hypothesis is $60.40081 \%$, and the external influence on this variable is $39.5992 \%$. This is obtained from the direct influence of the Law Enforcement variable on the Social Integration variable of $40.75225 \%$, and the indirect effect of the Law Enforcement variable on the Community Social Integration variable through the Social Discipline variable of $19.64856 \%$.

On another partial level, it turns out that Social Discipline has a real influence on Community Social Integration. This is shown by the path coefficient of the variable of 0.5003748 with the contribution of the influence of $25.37624 \%$, and the external influence on this variable is $74.62376 \%$.

In testing the main hypothesis, namely the effect of law enforcement on social discipline and social integrity of the community, it also shows a significant value. This is supported by the influence value of $62.90363 \%$. Thus, the theories on law enforcement and social discipline affect the social integration of the community significantly. This is because the results of testing the main hypothesis and sub hypotheses show that there is an influence between the research variables.

Quantitatively, the description above has shown that the variables of Law Enforcement and Social Discipline can have an influence on Community Social Integration. However, practically the factors that influence the Social Integration of the Community are not only caused by law enforcement and social discipline. This is evidenced by the influence of $37.09637 \%$ outside the research variables, namely Law Enforcement and Social Discipline.

\section{CONCLUSION}

Law Enforcement and Social Discipline simultaneously (together) have a significant effect on Community Social Integration. This is shown by the coefficient of determination which shows that the magnitude of the influence of Law Enforcement and Social Discipline on Community Social Integration is relatively large, while other factors not examined have a relatively very small effect on Community Social Integration. 
International Journal of Social Science (IJSS)

Vol.1 Issue.4 December 2021, pp: 423-430

ISSN: 2798-3463 (Printed) | 2798-4079 (Online)

DOI: https://doi.org/10.53625/ijss.v1i4.720

Partially, Law Enforcement and Social Discipline have a significant influence on Community Social Integration, meaning that Community Social Integration is determined by the existence of Law Enforcement and Social Discipline.

The partial effect of Law Enforcement on Social Discipline based on the test results has a significant effect. This is indicated by the magnitude of the coefficient value of the Law Enforcement Path to Social Discipline, meaning that the external influence on Social Discipline other than Law Enforcement is relatively small.

\section{REFERENCES}

[1] Atmasasmita, Romli. 2001. Reformasi Hukum, Hak Asasi Manusia \& Penegakan Hukum. Mandar Maju, Bandung.

[2] Busroh, Abu Daud \& Abu Bakar Busro. 1994. Asas-asas Hukum Tata Negara. Galia Indonesia, Jakarta.

[3] Campbeel, Tom. 1997. Tujuh Teori Sosial, Kanisius, Yogyakarta.

[4] Djohan, Djohermansyah. 1998. Kebijakan Percontohan Otonomi. Yarsif Watampone, Jakarta.

[5] Hossein, Bhenyamin. 2000. Reformasi Pemerintahan Daerah. Universitas Garut.

[6] Iskandar, Jusman. 2002. Manajemen Publik. Program Pascasarjana Universitas Garut

[7] Kaho, Josep Riwu. 1998. Prospek Otonomi Daerah di Republik Indonesia Rajawali Press, Jakarta.

[8] Koswara, E. 1999. Faktor-faktor yang Mempengaruhi Pelaksanaan Otonomi Daerah di Indonesia. UGM, Yogyakarta.

[9] Kusumaatmadja, Mochtar. 2000. Fungsi dan Perkembangan Hukum dalam Pembangunan Nasional. Gramedia Pustaka Utama, Jakarta.

[10] Manan, Bagir. 1996. Kedaulatan Rakyat, Hak Asasi Manusia dan Negara Hukum. Gaya Media Pratama, Jakarta.

[11] Mas'oed, Mochtar. 1993. Kebijaksanaan dan Pelaksanaan Kualitas Manusia dalam Pembangunan. Raja Grafindo Persada, Jakarta.

[12] Moekijat. 1995. Manajemen Personalia dan Sumber Daya Manusia. Mandar Maju, Bandung.

[13] Mulyatno. 1995. Kitab Undang-undang Hukum Pidana. Bina Aksara, Jakarta.

[14] Nawawi, Hadari. 1999. Metode Penelitian Sosial. Mandar Maju, Bandung.

[15] Rasyid, M. Ryaas. 1998. Kajian awal Birokrasi Pemerintahan Politik Orde Baru, Yarsif Watampone, Jakarta.

[16] Smith, J.S. 1995. Guide to Management. Bumi Aksara, Jakarta.

[17] Soekanto, Soerjono. 1995. Sosiologi Suatu Pengantar. Bina Aksara, Jakarta.

[18] Soepeno , Bambang. 1997. Statistik terapan. Rineka Cipta, Jakarta.

[19] Sugiyono. 1997. Metode Penelitian Administrasi. Alpabeta, Bandung.

[20] Sujatmo. 1994. Proses Pembuatan Undang-Undang Nomor 5 Tahun 1974. Bina Aksara, Jakarta. 
